\title{
Landscape Restoration Design of Guilin Lijiang River Basin Based on" City Betterment and Ecological Restoration"
}

\author{
Weiran Tian ${ }^{1}$, Ying Huang ${ }^{1, *}$ \\ ${ }^{1}$ College of Tourism\&Landscape Architecture , Guilin University of Technology, Guilin 541004, China
}

\begin{abstract}
As an important carrier of urban ecology, urban river channels have serious ecological problems that restrict the development of cities. Taking Lijiang River in Guilin as the research object, the field survey of the water system shape, water quality status, plant landscape and other aspects of the Lijiang River Basin was conducted to analyse its existing ecological problems. Based on the concept of "City Betterment and Ecological Restoration", the Lijiang River Basin ecological restoration and landscape repair work will be carried out from four aspects: water quality management, construction of natural river shape, coastal vegetation landscape ecological restoration, and water system landscape optimization design, so as to achieve a virtuous cycle of water ecosystem and promote sustainable development of landscape in Lijiang River Basin.
\end{abstract}

\section{Introduction}

As an important carrier of urban ecology, urban river course is not only an ecological space unit to alleviate "urban disease" and heat island effect, but also the best place for people to contact with the natural environment and enjoy recreation. In recent years, due to the accelerating economic growth, the urbanization process has been increasingly placed in an important position, and the deterioration of the ecological environment has been neglected. Problems such as poor river systems, degradation of aquatic ecosystems, and shrinkage of water areas in some cities have become increasingly prominent and severely restrict for the sustainable and healthy development of cities, it is necessary to vigorously carry out urban river ecological restoration work, restore the ecological cycle system with good water systems, and create a harmonious and beautiful living environment ${ }^{[1]}$.

In 2015, the Central Government first put forward the concept of "City Betterment and Ecological Restoration", which is a powerful measure to cure "urban disease" and protect urban ecological environment, a necessary process to adapt to economic development, and an important means for urban modernization transformation ${ }^{[2]}$. This study takes the ecological restoration of Lijiang River Basin in Guilin as an example, through field research on the Lijiang River Basin, the existing urban ecological problems are proposed, and the restoration strategy of urban water system landscape under the concept of "City Betterment and Ecological Restoration" is proposed to improve the water ecological environment of Lijiang River Basin.

\section{Theoretical overview}

\subsection{Connotation of "City Betterment and Ecological Restoration"}

"City Betterment and Ecological Restoration" includes "urban repair" and "ecological restoration", which embodies the transformation of urban development model and governance mode, both of which are related and different ${ }^{[3]}$. Among them, "ecological restoration" refers to the concept of re-ecology, taking corresponding restoration measures for the ecological environment damage and pollution that has been caused in the city, thereby improving the quality of the ecological environment and inhibiting the deterioration of the ecological environment; the main purpose of "urban repair" is the improvement of city appearance and landscape functions. It includes improving the quality of urban infrastructure and spatial environment, restoring historical context and landscape features, and enhancing urban characteristics and vitality. "Ecological restoration" and "urban repair" are related to each other and complement each other, providing a strong guarantee for protecting the urban ecological environment and achieving a virtuous cycle of the urban ecosystem.

\subsection{Principles of urban water system ecological governance}

Environmental improvement. According to the characteristics and existing problems of the river channel, the urban river system ecological governance should

\footnotetext{
* Corresponding author: 490498081@qq.com
} 
formulate corresponding rectification strategies. The designer should build suitable biological habitats in the river channel, select native aquatic plants, restore the natural riverbank shape according to local conditions, and promote the virtuous cycle of the river ecosystem.

Landscape aesthetics. The urban water system ecological management project should meet the requirements of landscape aesthetics, plan rational scheme, highlight landscape design, organically integrate river ecological restoration and landscape beautification, and meet the aesthetic and leisure requirements of tourists.

Ecological function. When restoring urban water system ecosystems, attention should be paid to the multi-level construction of vegetation landscapes along the water system, increasing plant diversity, constructing river ecological corridors, controlling river water and soil erosion, restoring the self-purification function of river ecosystems, and achieving a new dynamic balance.

\section{Hydrological features of Lijiang River Basin}

Lijiang River belongs to the Gui River in the Xijiang River system of the Pearl River Basin. It originates from Maoer Mountain, the highest elevation in north-eastern Guangxi, flows from north to south through Xing'an County, Lingchuan County, Guilin City District, Yangshuo County, and passes through the Chuanjiang River, Liudong River, Xiaorong River, Gantang River, Chaotian River, Yulong River and Jinbao River, then entered Pingle County and Wuzhou City. The total length of the Lijiang River is about $229 \mathrm{~km}$, and the drainage area is about $5830 \mathrm{~km}^{2}{ }^{[4]}$.

\subsection{Less sediment concentration}

The sediment of the Lijiang River mainly comes from the upstream Xing'an, Lingchuan and Taohua Rivers. It is formed by heavy rain and floods washing the ground and the river bank, mainly suspended sand. The change of sand content depends on the rainstorm and flood. The sand content in the flood period is large, the maximum measured sand content is $10.3 \mathrm{~kg} / \mathrm{m}^{3}$; the sand content in the dry season is less, and it is often close to $0 \mathrm{~kg} / \mathrm{m}^{3}$ in January, February, November and December each year, the average sand content for many years is $0.084 \mathrm{~kg} / \mathrm{m}^{3}$. The low sand content is due to the upstream river flowing through the mountainous area, high vegetation coverage, and low surface soil loss. At the same time, the downstream river bed is mainly composed of pebbles and sand, and the mud is very little. Therefore, the Lijiang River has become the river with the least sand content in Guangxi.

\subsection{Significant change in water volume}

The Lijiang River is a typical rainwater replenishment river ${ }^{[5]}$. Due to the impact of rainfall, the annual runoff distribution of the Lijiang River is uneven. The wet season is from March to August every year, concentrated in summer, and the dry season is from September to February of the following year, concentrated in winter. The runoff between the wet season and the dry season is very different (Table 1). At the same time, due to the narrow river channel, in every storm, the river rises sharply and the water level rises rapidly; after the storm, the river subsides and the water level drops sharply, causing a large water level difference.

Table 1. Lijiang River hydrological features distinguish between wet and dry season.

\begin{tabular}{|c|c|c|}
\hline & Wet season & Dry season \\
\hline $\begin{array}{c}\text { Water surface } \\
\text { width } / \mathrm{m}\end{array}$ & $100-200$ & $20-50$ \\
\hline Water depth $/ \mathrm{m}$ & $>1$ & $<0.6$ \\
\hline $\begin{array}{c}\text { The proportion } \\
\text { of annual runoff }\end{array}$ & $77.5 \%$ & $22.5 \%$ \\
\hline
\end{tabular}

\subsection{Long flood season}

The Lijiang River is the earliest river in Guangxi during the flood season, and the spring flood is generally coming at the end of February. Precipitation in the Lijiang River Basin is decreasing from northwest to southeast. The upper reaches of the Huajiang and Chuanjiang Rivers are one of the high-value rainstorm areas in the country and the main source of floods in the Lijiang River. Due to the early arrival of the southeast monsoon in summer and the typhoon in autumn, the rainy season of the Lijiang River is longer, and the flood season is mostly from March to September, which lasts for half a year.

\section{Existing ecological problems}

\subsection{Deterioration of water quality}

Because Lijiang River is a rain-fed river, the depth of the river is greatly affected by rainfall, so seasonal dry water is more serious. The high-quality hydrological conditions of the Lijiang River require the water volume of the river to reach $60 \mathrm{~m}^{3} / \mathrm{s}$. However, during the dry season, the water volume of the river decreases, and the self-dilution and self-purification ability of water body decreases. At the same time, with the continuous discharge of domestic sewage and agricultural pollution along the banks of the river, algae plants such as Euglenophyta, Cyanophyta and plankton rapidly multiply, and the quality of the water environment gradually deteriorates.

\subsection{Natural river bank damaged}


By referring to data and on-site investigation, Lijiang River Basin is a long multi-tributary channel with narrow upper and lower channels and wide middle channel, which originally exhibited different natural riverbank shapes from top to bottom due to the influence of terrain (Table 2). However, due to frequent human activities along the Lijiang River in recent years, the natural river bank has been subject to various degrees of man-made damage, especially the straightening of the bank line, the reinforcement of hard concrete revetment, and the channelization of the river bed, which have seriously damaged the water body itself. The ecological circulation system, the living environment of aquatic plants and the natural vegetation on both sides of the straits are seriously interfered.

Table 2. Riparian morphology of each section of Lijiang River.

\begin{tabular}{|c|c|c|}
\hline Reach & $\begin{array}{l}\text { Morphological } \\
\text { characteristics }\end{array}$ & $\begin{array}{c}\text { Characteristics of } \\
\text { tidal flats }\end{array}$ \\
\hline Guilin -- Dawei & $\begin{array}{c}\text { First terrace, open } \\
\text { valley, tidal flat } \\
\text { development }\end{array}$ & Sand mass \\
\hline Dawei -- Xingping & $\begin{array}{l}\text { More precipitous } \\
\text { mountains, tidal } \\
\text { flat undeveloped }\end{array}$ & -- \\
\hline $\begin{array}{l}\text { Xingping -- } \\
\text { Yangshuo }\end{array}$ & $\begin{array}{l}\text { Gentle slopes and } \\
\text { hills are the main, } \\
\text { tidal flat } \\
\text { undeveloped }\end{array}$ & -- \\
\hline $\begin{array}{l}\text { Yangshuo -- } \\
\text { Xiaowan }\end{array}$ & $\begin{array}{c}\text { First terrace, open } \\
\text { valley, tidal flat } \\
\text { development }\end{array}$ & Sand mass \\
\hline Xing-an & $\begin{array}{c}\text { River low terrace, } \\
\text { high floodplain }\end{array}$ & $\begin{array}{l}\text { Clay and gravel } \\
\text { beds }\end{array}$ \\
\hline Guilin city & $\begin{array}{c}\text { First stage } \\
\text { artificial platform }\end{array}$ & $\begin{array}{c}\text { Gravel and egg } \\
\text { layers }\end{array}$ \\
\hline
\end{tabular}

\subsection{Poor flood control and drainage capacity}

In recent years, serious phenomena such as digging sand and gravel at random, large-scale loosening of navigation channels, and high-density and frequent navigation of large cruise ships have caused serious water leakage and severe erosion of the river bank (Figure 1). During the flood season, rivers cannot function normally. Floods often cause destructive inundation along the coast. The collapse of river banks and frequent flooding have greatly damaged the coastal landscape of the Lijiang River Basin.

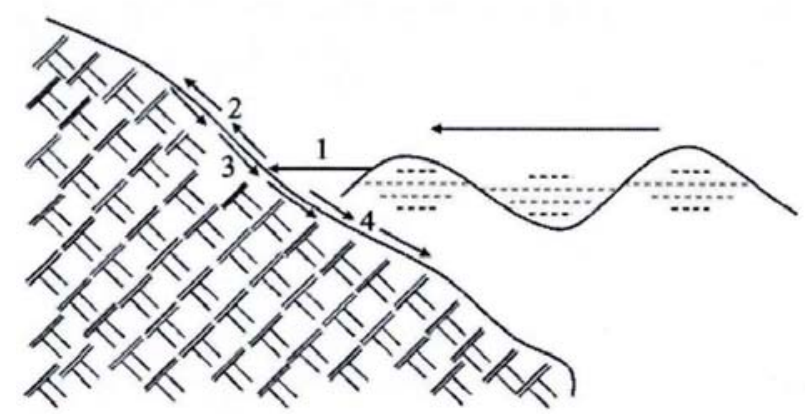

Fig. 1. Erosion of bank slope by surge of cruise ship.

\subsection{Coastal green vegetation destroyed}

The investigation found that there are 7 vegetation types along the Lijiang River, including temperate coniferous forest, warm coniferous forest, evergreen broad-leaved forest, evergreen deciduous broad-leaved mixed forest, deciduous broad-leaved forest, deciduous broad-leaved shrub and meadow, showing different plant community landscapes according to the altitude topography (Table $3)$.

Table 3. Growth distribution of plant communities in Lijiang River Basin.

\begin{tabular}{|c|c|c|}
\hline $\begin{array}{c}\text { Area of plant } \\
\text { growth }\end{array}$ & $\begin{array}{c}\text { Main vegetation } \\
\text { type }\end{array}$ & $\begin{array}{c}\text { Main plant } \\
\text { species }\end{array}$ \\
\hline $\begin{array}{c}\text { Limestone rock } \\
\text { hills }\end{array}$ & $\begin{array}{c}\text { Temperate } \\
\text { coniferous forest, } \\
\text { deciduous broad- } \\
\text { leaved bushes, } \\
\text { meadows }\end{array}$ & $\begin{array}{c}\text { Rhododendron, } \\
\text { Myrtle, Mangwa, } \\
\text { Pinus massoniana, } \\
\text { etc. }\end{array}$ \\
\hline Hilly mountain & $\begin{array}{c}\text { Warm coniferous } \\
\text { forest, deciduous } \\
\text { broad-leaved } \\
\text { forest }\end{array}$ & $\begin{array}{c}\text { Tallow, Ginkgo, } \\
\text { Chinese fir, } \\
\text { Cypress, etc. }\end{array}$ \\
\hline Bank buffer zone & $\begin{array}{c}\text { Evergreen broad- } \\
\text { leaved forest, } \\
\text { evergreen } \\
\text { deciduous broad- } \\
\text { leaved mixed } \\
\text { forest }\end{array}$ & $\begin{array}{c}\text { Maple Poplar, } \\
\text { Autumn Maple, } \\
\text { Elaeagnus } \\
\text { angustifolia, } \\
\text { Shuirong, etc. }\end{array}$ \\
\hline
\end{tabular}

Affected by karst landform, Lijiang River riparian zone is an ecological interlaced zone between Lijiang River and the land. It is rich in plant species and stable in plant communities, which has a positive impact on maintaining the water ecological security pattern in the Lijiang River Basin. However, the continuous development of tourism on the Lijiang River has caused serious damage to the coastal vegetation over the years. The random felling of trees along the coast, the trampling of cattle and sheep, and the dumping of domestic garbage can be seen everywhere. The ecological stability of the plant community is seriously affected, and the native vegetation gradually disappears.

\section{Landscape restoration strategies}

\subsection{Water quality management}

In view of the water pollution in Lijiang River basin, biofilm technology and ecological floating island technology can be used to purify the water. Biofilm technology can be applied in places with dense population and high pollutant discharge along the Lijiang River. It uses natural materials (such as pebbles and gravel) and composite materials (such as fibres) as carriers to provide larger attachment surfaces for microorganisms, increasing the contact area between microorganisms and pollutants, strengthening the degradation of pollutants, effectively removing pollutants such as organic matter and ammonia nitrogen in water bodies, and purifying river water bodies. 
In view of the characteristics of the space utilization of the tidal flat in the Lijiang River Basin, ecological floating islands can be constructed to clean up the water quality during the ecological restoration process. Ecological floating island technology is a kind of plant water purification project. It uses a thin foam material to make a floating island carrier. A floating island is set up in local waters, on which native aquatic plants such as canna, cattail, yellow iris, etc. are planted. The lower plant roots form a habitat for fish and aquatic insects. While beautifying the water landscape, through the absorption of the aquatic plant roots, the organic matter and ammonia nitrogen and other elements in the water body are absorbed to achieve the effect of purifying water quality and improving the landscape.

\subsection{Constructing natural river channels}

According to the research of river ecologists, the change of the longitudinal slope of the river, the meandering nature of the plane shape, and the diversity of the geometry of the cross section of the river are of great significance to the aquatic biodiversity of the river ${ }^{[6]}$. In view of the impact of the artificial river bank on the damage to the water environment, in the later stage of the Lijiang landscape improvement, ecological bank protection technology and methods of restoring the natural river shape can be used to transform and upgrade it. For example, in the essence section of the Yangshuo scenic area in the Lijiang River Basin, in order to provide tourists with a better view of the landscape, the river bank can be built into a natural curved shape. Revetment uses plant revetment and plant engineering composite revetment technology, which not only meets the requirements of flood control, but also improves the growth environment of aquatic organisms, and enriches the river bank landscape.

\subsection{Ecological restoration of coastal vegetation landscape}

The restoration of vegetation landscape along the Lijiang River should be adapted to local conditions, responding to the landscape needs and topographical features of each river section.

\subsubsection{Tourist viewing area}

The river section where the tourist viewing area is located is generally the main landscape corridor along the Lijiang River. Therefore, the plant configuration should be ecologically restored from both horizontal and vertical scales, combining aquatic plants and terrestrial plants to enrich the seasonal changes of plants and enhance the landscape of coastal plants. For example, when allocating plants on a horizontal scale, according to the characteristics of the community, the waterfront to the landside zone generally follow the community structure characteristics of the embankment community, the wet community, and the terrestrial community; when performing vertical-scale plant allocation, the waterfront to the land coast is generally progressively advanced by grass, shrub grass, and joe shrub, and is based on evergreen tree species. At the same time, it is complemented by coloured leaf tree species such as Luan tree, Ginkgo biloba, and Pistacia chinensis to enrich the coastal landscape.

\subsubsection{Village gathering area}

This section is a densely populated residential area along the Lijiang River, and the human activity is more obvious. Therefore, in the daily life, it is necessary to strengthen the ecological protection awareness of the original residents, prohibit the random dumping of domestic garbage, encourage the use of pollution-free planting techniques when farming, and avoid using toxic pesticides and fertilizers to prevent water pollution. At the same time, the farmland along the Lijiang River basin has beautiful scenery, and various economic crops plantation forests and agricultural landscape fields themselves form a natural green landscape barrier. Therefore, in the configuration of plant communities, economic benefits and landscape effects should be considered together. On the basis of appropriate human intervention, the relationship between continuous planting and scattered planting is handled with aesthetic landscaping techniques to bring better visual landscape experience for tourists.

\subsubsection{Ecological sensitive area}

The ecologically sensitive area is mainly located in the upper reaches of Lijiang River, and its protoplasmic ecosystem is strong. When landscape construction is carried out, 3S technology (RS, GIS, GPS) can be used to analyse the ecological suitability of the area, delineate the ecological protection scope, and emphasize the ecological buffer area. The designer should strictly control the number of exotic plants, limit the disturbance of human activities, maximize the maintenance of the original nature of the ecosystem, and provide visitors with a native plant community landscape.

\subsection{River landscape design optimization}

\subsubsection{Optimize the layout and bring benefits to the people}

In order to fully display the landscape features of the Lijiang River Basin, it can be divided into two major areas of ornamental attractions and tourist attractions based on the spatial distribution of natural scenery, landscape features and current conditions of use. The scenic spots should enhance the scenic beauty along the river bank and the scenic spots should strengthen the tourists' experience, add service facilities, and beautify the environment. By optimizing the landscape layout of ornamental and tourist attractions along the Lijiang River, the sustainable development of tourism in the Lijiang River Basin can be promoted. 


\subsubsection{Strengthen characteristics and the connection between mountains and rivers}

The so-called "Guilin mountains and rivers are the best in the world", the landscape pattern of Guilin's urban and water-dependent landscapes is very unique, and the characteristics of the Lijaing River can be summarized with four words :clear, strange, clever, and change, where strange, clever, and change are inseparable from the surrounding mountains. In the background, the water of the Lijiang River and the surrounding mountains together form a hundred-mile picture. Therefore, when optimizing the landscape design of the water system of the Lijiang River Basin, more attention should be paid to strengthen the relationship between the mountains and the water, and strengthen the characteristics of Guilin's landscape.

\subsubsection{Unify planning and improve urban function system}

The strategy of "City Betterment and Ecological Restoration" is to use a systematic way of thinking for landscape planning and design, and the layout of urban functions should be carried out in the urban pattern ${ }^{[7]}$. Therefore, in the landscape design of the Lijiang River Basin, it is necessary to coordinate the overall situation and form an overall spatial morphological feature. For example, the designer can limit the diversity of architectural colours, volumes, and forms on both sides of the Lijiang River Basin, carry out unified planning for landscape facilities such as lighting systems and identification systems of scenic spots along the coast, and integrate regional cultural characteristics to form an overall unified and distinctive waterfront space shape.

\section{Conclusion}

"City Betterment and Ecological Restoration" is a new method and new concept for treating urban diseases, which can solve the contradictory relationship between economic development and environmental protection. As an important carrier of urban ecology, the urban water system affects the quality of life of urban residents and restricts the sustainable development of urban ecosystems. The concept of "City Betterment and Ecological Restoration" runs through the comprehensive ecological management project of urban water systems, which is an important guarantee for conforming to the development of ecological civilization and achieving the harmonious symbiosis between man and nature. Taking the ecological landscape restoration of Guilin Lijiang River Basin as an example, based on the basic idea of ecological restoration as the core and landscape repair optimization as the focus, the strategies of "water system repair" are proposed which conclude water quality management, the construction of natural river channels, the ecological restoration of the coastal vegetation landscape, and the optimization design of the water system landscape. That provides a method for creating a sustainable and high-quality landscape environment, and promotes the sustainable and healthy development of the Lijiang River valley landscape.

\section{Acknowledgements}

We thank the National Key R\&D Program of China (2019YFC0507503) and the National Natural Science Foundation of China (Nos.51968012) for funding support.

\section{References}

1. E. Pramova, B. Locatelli, M. Brockhaus, et al. Ecosystem Services in the National Adaptation Programmes of Action[J]. Climate Policy, 2012, 12(4): 393-409.

2. Y. Han, X.H. Pu, Q. Liang. Urban Water System Landscape Planning in the Perspective of City Betterment and Ecological Restoration-A Case Study of the Ecological Planning for Water System Connection in Xinxiang City[J].Chinese Landscape Architecture, 2018,34(08):27-32.

3. J.N. Huang, M.X. Xu, Z.Y. Zhang. Weifang Urban River Regulation Based on City Betterment and Ecological Restoration[J]. Planners,2017,33(S2):2226.

4. X.M. Qin, B.H. He, L.N. Shen, et al. Characteristics of Soil and Water Loss in the Lijiang River Basin and Soil Erosion Factors in Typical Karst Small Watersheds[J].Carsologica Sinica, 2018,37(03):351360.

5. Y. Huang, X.X. Que, C.Y. Li. Study on Landscape Ecological Restoration Technology of Land/inland Water Ecotones along Li River[J]. Journal of Southern Agriculture,2013,44(10):1700-1704.

6. Z.R. Dong, D.Y. Sun, J.Y. Zhao, et al. Progress and Prospect of Eco-hydraulic Engineering [J]. Journal of Hydraulic Engineering,2014,45(12):1419-1426.

7. S.V. Smith, W.H. Renwick, J.D. Bartley, et al. Distribution and Significance of Small, Artificial Water Bodies across the United States landscape[J]. Science of The Total Environment, 2002, 299(1): 21-36. 